\title{
Thermal behaviour of ceramics obtained from the kaolinitic clays of Terra Alta, Catalonia, Spain
}

\author{
M. Garcia-Valles ${ }^{1}$ (D) D. Cuevas ${ }^{2} \cdot$ P. Alfonso ${ }^{2} \cdot$ S. Martínez ${ }^{1}$
}

Received: 3 May 2021 / Accepted: 10 September 2021 / Published online: 15 October 2021

(c) The Author(s) 2021

\begin{abstract}
The thermal properties and evolution of mineralogy and colour of kaolinitic clay from the Terra Alta region were studied. The mineralogy of these materials consists mainly of kaolinite (13-27 mass\%) and quartz (48-86 mass\%). Minor illite, hematite, $K$-feldspar and calcite also occur. The linear expansion and absorption curves were used to predict the optimal firing temperature of the raw clays. During firing, from $1100{ }^{\circ} \mathrm{C}$ the water absorption decreases steeply, due to an increase in liquid phase, which penetrates into the pores and close the porosity. At this temperature, the firing shrinkage increases progressively. The fired clays are mainly composed of quartz, cristobalite and mullite, with minor hematite and rutile. Mullite starts to appear at $1050-1100{ }^{\circ} \mathrm{C}$. SEM observations show that porosity decreases with the firing temperature. The colour properties were measured in the raw clays and in the fired bricks at different temperatures. The lightness, $L^{*}$, is lower in the fired test pieces respect to the natural clays. This colour varies according to the hematite content, being from white to reddish in the fired samples.
\end{abstract}

Keywords Kaolinitic clays $\cdot$ Mineralogy $\cdot$ Firing $\cdot$ Shrinkage $\cdot$ Mullite

\section{Introduction}

Kaolinitic materials have acquired an increasing importance by the use of ceramics in new industrial applications [1,2] in addition to the classical uses. Determining the optimal firing temperature for a clay is essential to produce quality ceramics to use not more energy than is strictly necessary, thus the mechanical properties of the fired clays deepen on these temperatures $[3,4]$. The firing conditions are critical parameters to define the colour in ceramics, which is one of the hardest problems in the ceramic industry [5]. This is because the firing of a clay modifies the mineralogy of the ceramic body and this can influence in the colour [6] and other properties of the ceramics [7]. The mineralogical, textural and colorimetric evolution of a clay with temperature will determine its industrial use within the scope of ceramic materials. The mineral phases have stability at certain temperatures, being

M. Garcia-Valles

maitegarciavalles@ub.edu

1 Departamento de Mineralogia, Petrologia i Geologia Aplicada, Universitat de Barcelona, Barcelona, Spain

2 Departamento d'Enginyeria Minera, Industrial i TIC, Universitat Politècnica de Catalunya, Manresa, Spain transformed into a more stable structures during the thermal treatment and then, they play a determinant role in the firing process of a ceramic. To determine the thermal behaviour of the raw materials will be essential to find the ceramics with optimal properties and the firing temperature to apply in the industrial product.

In the region of Terra Alta, southern Catalonia, Spain, kaolinitic clay deposits occur as lateritic horizons of Upper Cretaceous age located in the Mora Basin. Kaolin occurs in two main areas close to the localities of Horta de Sant Joan (HS) and Pinell de Brai (PnB) that were previously mined for kaolinitic clays, and the PnB area is currently mined. The chemical and mineralogical characterization of these materials has already been reported [8]. In the present work, the thermal properties of the Terra Alta kaolinitic clays were studied to determine their sintering behaviour and to know the mineral phases formed during the thermal treatment to be used to stablish the optimal temperature of the kiln control. The influence of temperature in the evolution of the colour paste also was also evaluated. 


\section{Materials and methods}

Kaolinitic clays from HS and PnB areas were used to determine their thermal behaviour. Twelve samples were selected from this area, six of them were detailed studied previously [8] and six additional samples were obtained in a more detailed sampling in zones selected from the data of the previous study.

The raw clays were air-dried and then oven-dried to $105{ }^{\circ} \mathrm{C}$. Tests pieces from all the samples have been formed following the UNE-EN ISO 10545-3 standard [9] to determine the water absorption and linear shrinkage. The test pieces were sintered in an electric furnace at different temperatures between 1050 and $1300{ }^{\circ} \mathrm{C}$. The thermal cycle was divided into three steps: (1) from room temperature to $70{ }^{\circ} \mathrm{C}$ a rate of $1{ }^{\circ} \mathrm{C}$ was used, (2) an increase in the rate at $1.5^{\circ} \mathrm{C}$ up to the sintering temperature was applied, (3) a holding time of $120 \mathrm{~min}$ at this temperature followed was before cooling.

The chemical and mineralogical composition of kaolinitic clays was determined in all the samples using the same equipment and methodology reported previously [8]. The mineralogical characterization was completed with $\mathrm{X}$ ray powder diffraction (XRD) using oriented aggregates. The XRD patterns were obtained for oriented samples after the following pre-treatments: air drying at room temperature, saturation with ethylene glycol and after heating at $400{ }^{\circ} \mathrm{C}$ and $550{ }^{\circ} \mathrm{C}$ for $1 \mathrm{~h} \mathrm{[10].} \mathrm{In} \mathrm{addition,} \mathrm{XRD} \mathrm{was} \mathrm{used}$ to determine the mineralogy of the ceramic paste fired at several temperatures. Identification and semiquantitative evaluation of phases were made on PANanalyticalX'Pert HighScore software. The textures in the tests pieces were observed by scanning electron microscopy (SEM) using an environmental electron microscope Hitachi TM-1000 with an energy-dispersive X-ray spectrometer (EDS).

Thermal evolution of the clays was obtained by Differential Thermal Analysis and Thermogravimetry (DTA-TG) in the same conditions as in a previous study [8].

Dilatometric curves were obtained using a Linseis horitzontal dilatometer L76/1550. The experiment was carried out from room temperature to $1300{ }^{\circ} \mathrm{C}$ at a heating rate of $10{ }^{\circ} \mathrm{C} \mathrm{min}{ }^{-1}$, in a static-air atmosphere. The kiln firing curves were obtained from the dilatometric data following the method indicated in Vasić et al. [11].

The colour properties were measured in the raw kaolinitic clays and in the fired samples at different temperatures. Colour was defined by measuring the spectral diffuse reflectance according to the CIE, $1931 \mathrm{XYZ}$ colour space (CIE, Comission Internationale de l'Eclairage), which measures colour spaces and calculates the chromatic parameters [11]. These parameters were measured with a CM-700d Konica-Minolta spectrophotometer over the visible range (400 $\mathrm{nm}$ to $700 \mathrm{Hnm}$ wavelength range). The spectrophotometer was fitted with a barium sulphate coated integrating sphere, and a standard illuminate $\mathrm{C}$ was used as a light source. A colorimeter is designed to evaluate the colour of a material according to international standards [12]. The description of the colour was based on three parameters: lightness, saturation and intensity [13], which were based on the use of three coordinates, $L^{*}, a^{*}$ and $b^{*} . L^{*}$ indicates lightness, 100 being white colour and 0 black; $a^{*}$ and $b^{*}$ are the chromatic coordinates: $+a^{*}$ is the red axis, $-a^{*}$ is the green axis, $+b^{*}$ is the yellow axis and $-b^{*}$ is the blue axis.

\section{Results and discussion}

\section{Chemistry and mineralogy of raw materials}

Horta de Sant Joan clays are composed of $\mathrm{SiO}_{2}$ 56.4-70.4 mass\%, $\mathrm{Al}_{2} \mathrm{O}_{3}$ 14.4-24.1 mass\%, and $\mathrm{Fe}_{2} \mathrm{O}_{3}$ 4.40-6.82 mass\%, except one value of 0.80 mass\%. For $\mathrm{PnB} \mathrm{SiO}_{2}$ 55.92-79.62 mass\%, $\mathrm{Al}_{2} \mathrm{O}_{3}$ 10.46-24.65 mass\%, and $\mathrm{Fe}_{2} \mathrm{O}_{3}$ 5.80-10.90 mass\%. $\mathrm{K}_{2} \mathrm{O}$ is richer in $\mathrm{PnB}$, with average values of 0.11 mass\% of $\mathrm{Na}_{2} \mathrm{O}, 0.95$ mass $\%$ of $\mathrm{K}_{2} \mathrm{O}$, and 0.40 mass\% of $\mathrm{CaO}$. In $\mathrm{HS}$ the average contents are 0.04 mass\% of $\mathrm{Na}_{2} \mathrm{O}, 0.29$ mass\% of $\mathrm{K}_{2} \mathrm{O}$, and 0.77 mass\% of $\mathrm{CaO}$. $\mathrm{TiO}_{2}$ from both areas is relatively homogeneous, with 0.89 to 1.27 mass\%.

The mineralogy of kaolinitic materials from HS and PnB was reported in a previous article [8]. In the present research, the characterization was extended to a wider area and composition of clays confirmed with XRD of oriented samples. The new data confirmed that mineralogy is manly composed of quartz, kaolinite and minor hematite, $K$-feldspar, illite and rutile (Fig. 1). Sample HJ-5 belongs to a layer that outcrops

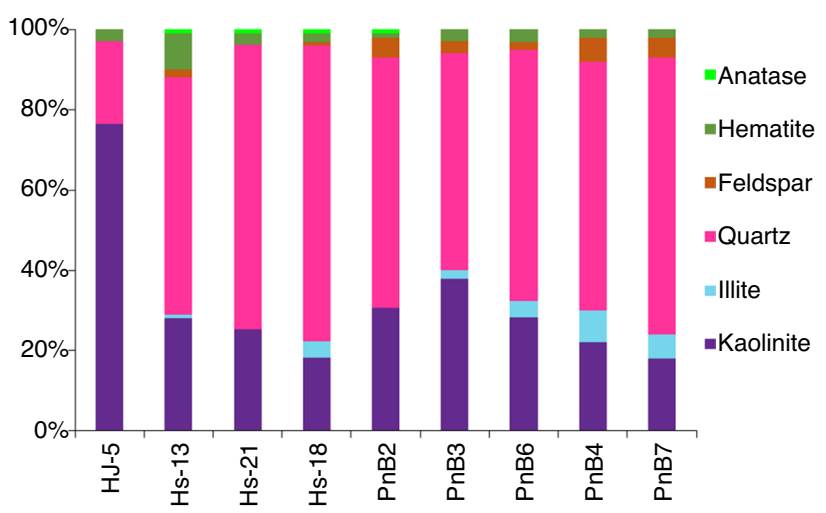

Fig. 1 Mineralogical content of representative samples from HS and PnB areas. HJ-5 sample data is from [8] 
Fig. 2 Dilatometric curves of a HS kaolin and $\mathbf{b}$ PnB kaolin (a)

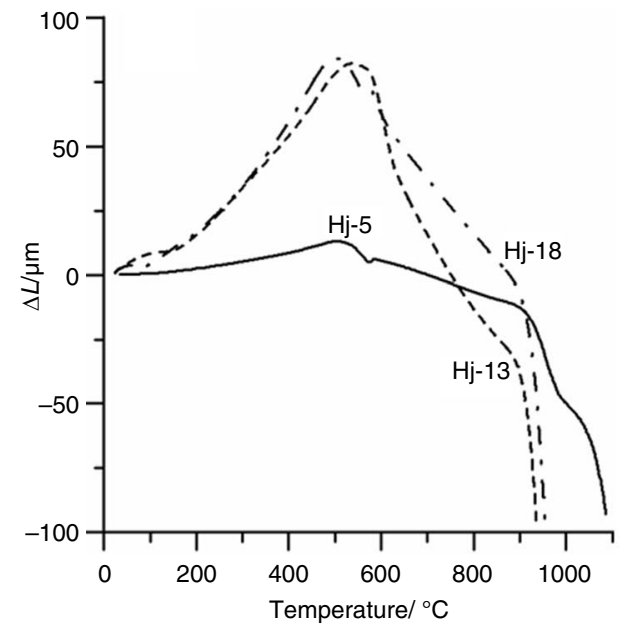

(b)

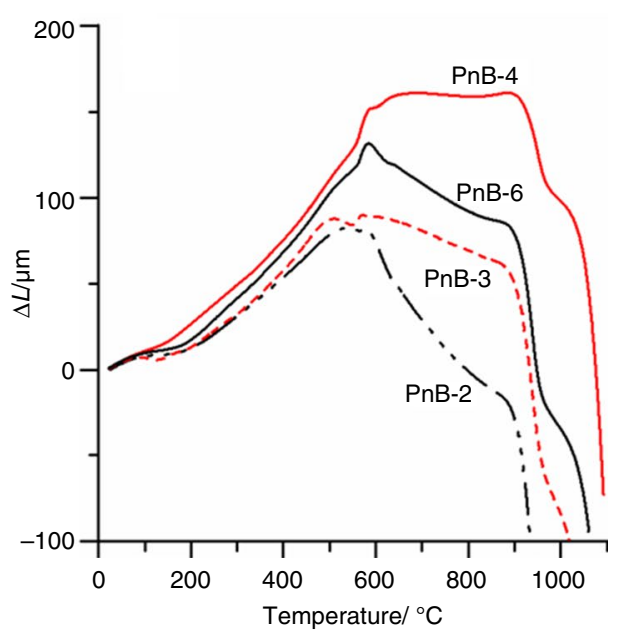

in HS [8] and represents the richest kaolin outcrop of the area, and it is used only for comparative behaviour of a kaolinite-rich sample. All the other areas have a kaolinite content lower than 50 mass\%, with a mean value about 25 mass $\%$.

(a)

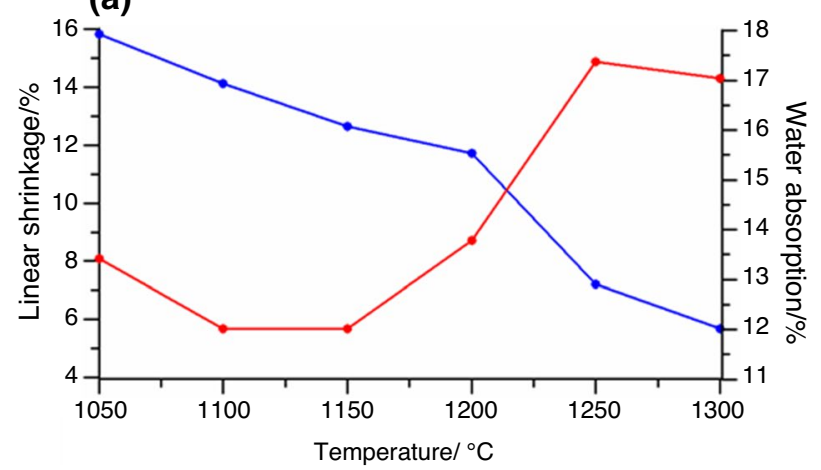

(b)

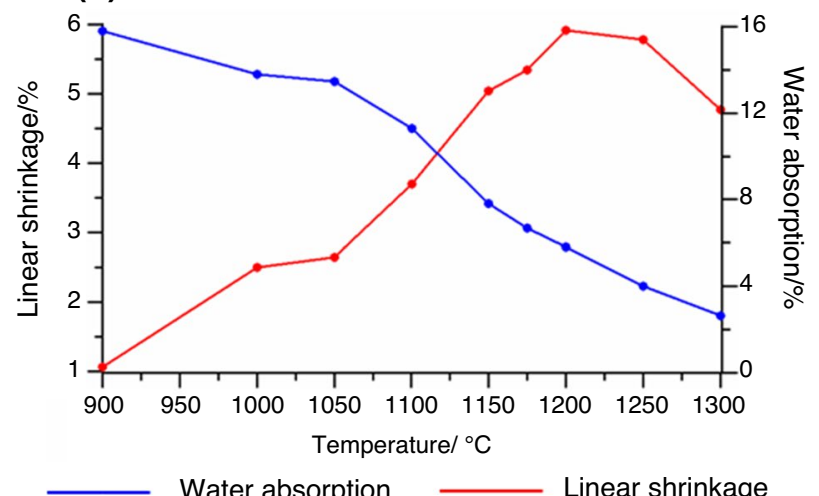

Fig. 3 Variation of the linear shrinkage of the test pieces and the water absorption with temperature. a HS clays, b PnB clays

\section{Thermal properties}

The DTA-TG indicates the mineralogical changes with the increase in temperature. The results confirm and broaden data previously obtained [8]. The first endothermic peak, $150-190{ }^{\circ} \mathrm{C}$, is attributed to the release of adsorbed water. The second endothermic occurs at $520-550{ }^{\circ} \mathrm{C}$ and is mainly due to the dehydroxylation of kaolinite. The exothermic occurs at $960-980{ }^{\circ} \mathrm{C}$ and corresponds to the formation of the $\gamma-\mathrm{Al}_{2} \mathrm{O}_{3}$ spinel-type phase from metakaolinite [8, 14].

Dilatometric curves indicate the dimensional changes during firing of the raw materials. These curves are the result of the thermal expansion of all the phases in the material, mainly due to the effect of clays and quartz [15]. In the kaolinitic clays of Terra Alta, a correlation between the clays content (kaolinite + illite) and the expansion is observed (Fig. 2). The lowest expansion occurs in the materials with lower quartz content (Fig. 2a curve of sample HJ-5), where

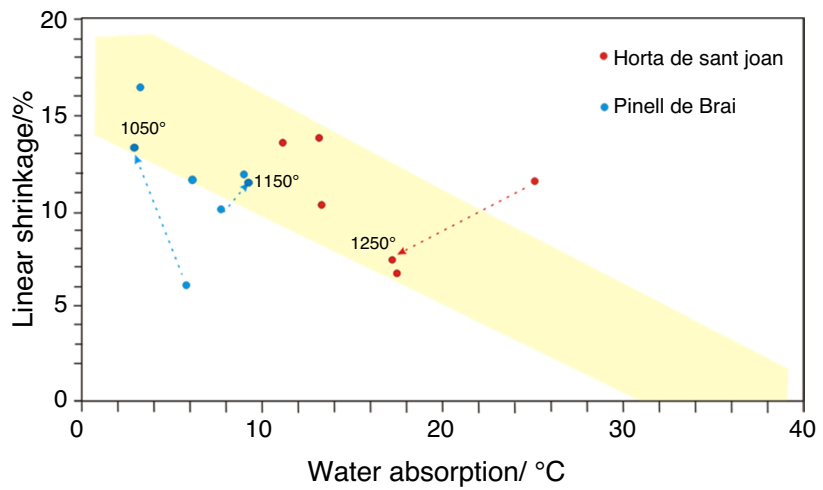

Fig. 4 Relationship between water absorption and linear shrinkage in fired kaolins. The yellow area indicates the overall firing behaviour of commercial kaolins [22]. Samples treated at $1200{ }^{\circ} \mathrm{C}$. In case they plot out the commercial region an arrow indicates their firing temperature 
(a)

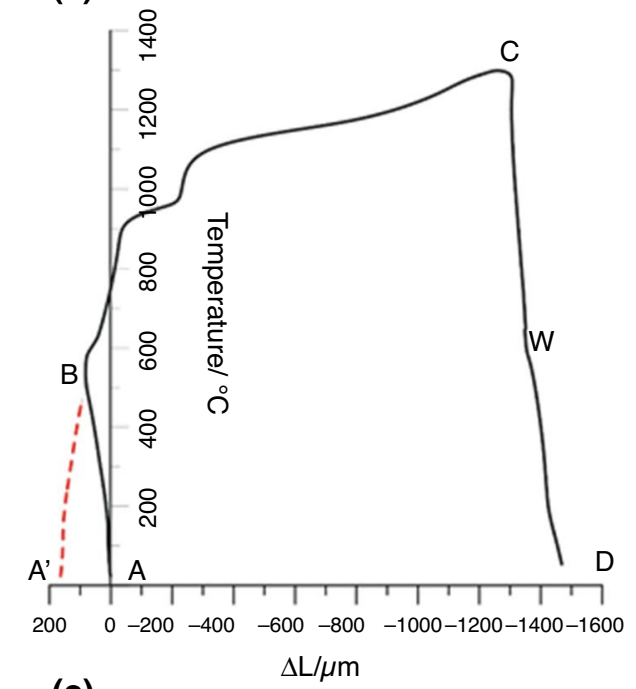

(c)

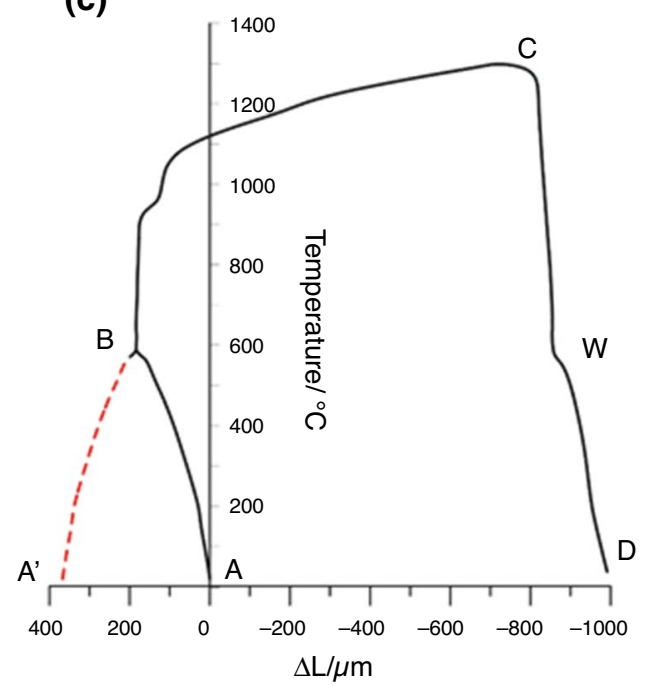

(b)

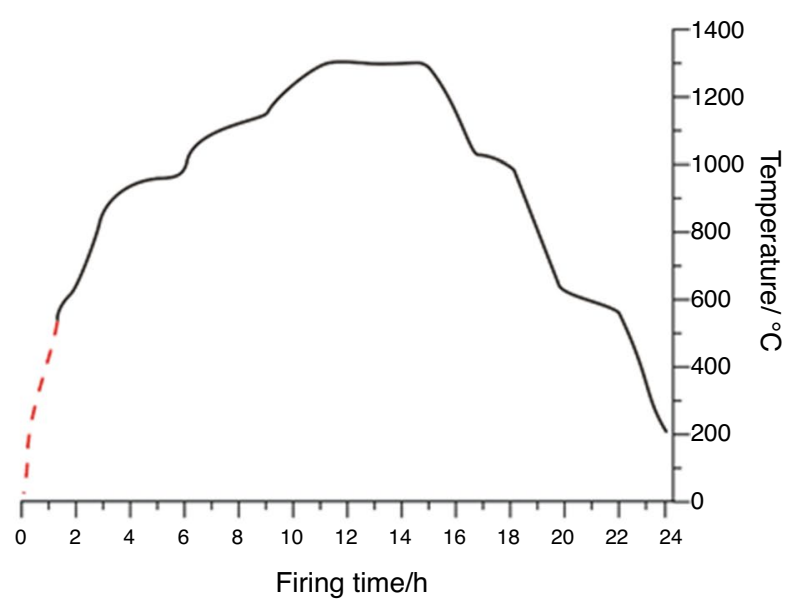

(d)

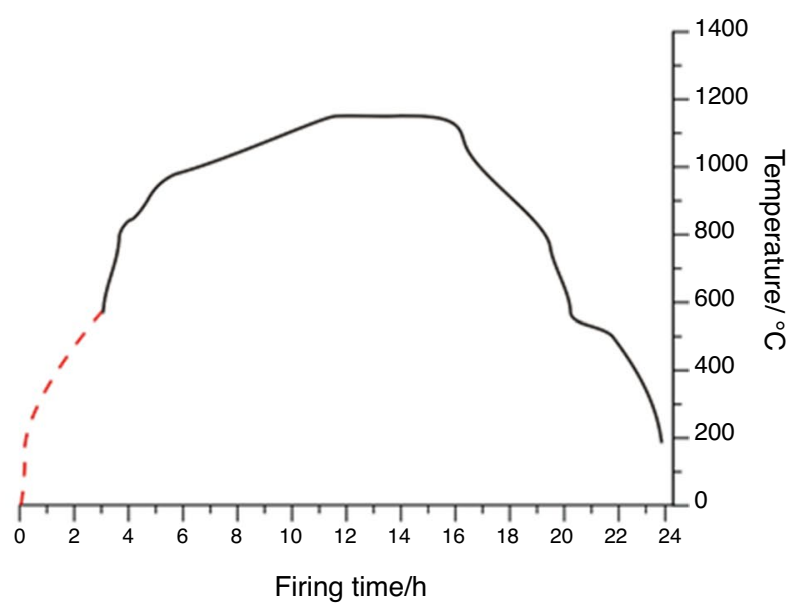

Fig. 5 Firing curves for a HS kaolin and $\mathbf{b}$ PnB kaolin

there is only a small expansion. When the content of quartz increases the expansion also increases, up to $500-600{ }^{\circ} \mathrm{C}$ and, in the case of the HS samples, this is followed by a shrinkage up to about $900{ }^{\circ} \mathrm{C}$ (Fig. 2a). This expansion is due to the dehydroxylation of kaolinite and transformation into metakaolinite and to the polymorphic transformation of $\alpha$-quartz to $\beta$-quartz. At temperatures higher than $900{ }^{\circ} \mathrm{C}$, the shrinkage is attributed to the transformation of metakaolinite and illite into a spinel-like structure and amorphous $\mathrm{SiO}_{2}[8,16,17]$. The changes after $900{ }^{\circ} \mathrm{C}$ are related to the vitrification, which is favoured by the breakdown of illite and liberation of fluxing oxides [18]. In the PnB clays the same behaviour is observed for the first expansion stage but it is followed by another stage of slight expansion or moderate shrinkage (Fig. 2b). Samples with a sill between 600 and $900{ }^{\circ} \mathrm{C}$ are those with illite contents (6-8 mass\%) and this sill is attributed to the more moderate release of structural water in illite [19]. This stage is followed by a steeply shrinkage.

The representation of the water absorption and linear shrinkage respect to the temperature in the same plot is known as gresification curves [18] and these are used to 


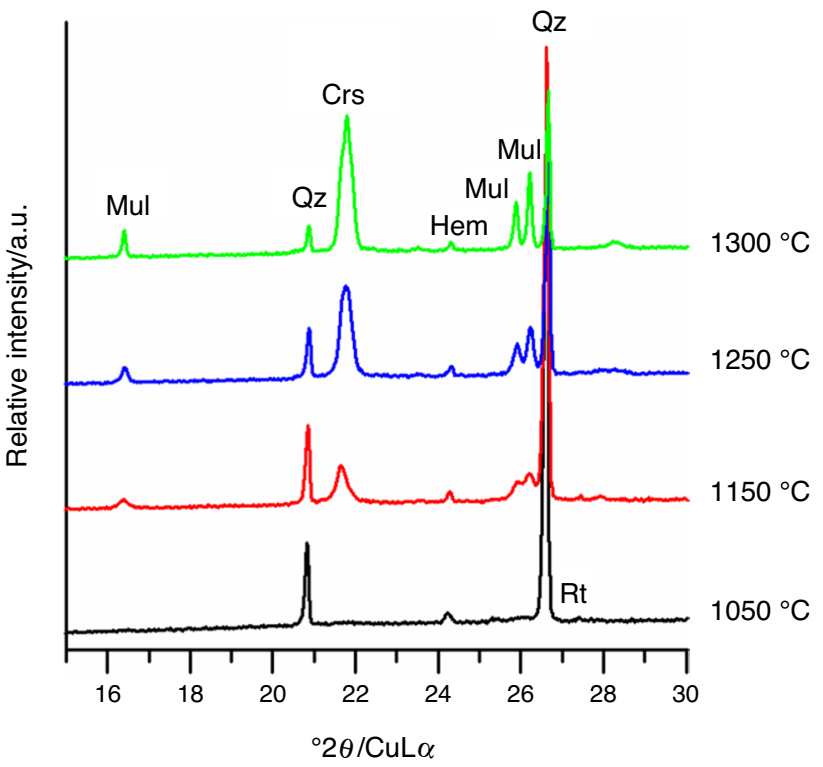

Fig. 6 Mineral composition of the crystalline phases of representative fired test pieces. a HS, b $\mathrm{PnB}$

predict the optimal firing temperature of the raw clay to minimize the processing costs, since it allows to determine when the balance between the hardness of the ceramics and the minimum porosity was achieved.

The evolution of the water absorption and linear shrinkage with the increase in the treatment temperature were used to obtain the firing conditions. The relationships between water absorption and linear shrinkage follow an inverse correlation. In the Terra Alta clays (Fig. 3), the shrinkage increases slowly up to a temperature comprised between $1050{ }^{\circ} \mathrm{C}$ (HS kaolin) and $1200{ }^{\circ} \mathrm{C}$ (PnB kaolin), followed by an abrupt increase produced by the appearance of a liquid phase [4]. This increase facilitates the water circulation and penetration into the pores and finally, closes the porosity;

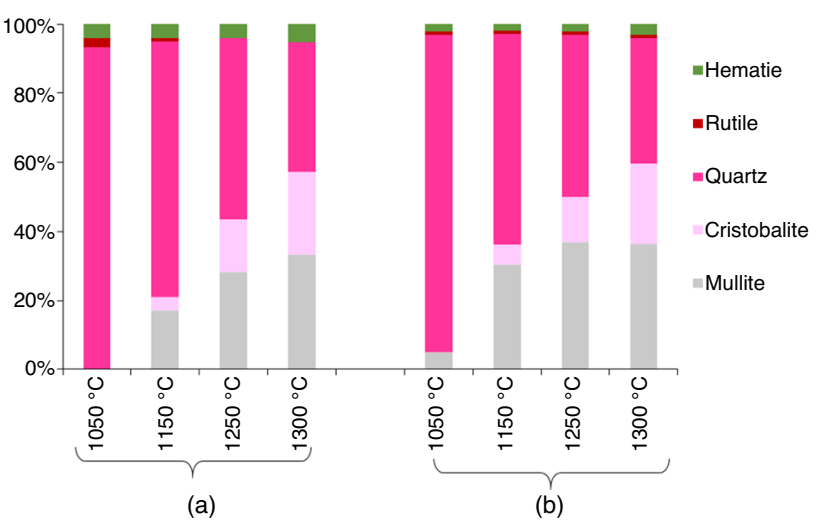

Fig. 7 XRD of a PnB kaolin fired at different temperatures. Qz, quartz; Crs, cristobalite; Mul, mullite; Hem, hematite; Rt, rutile as a consequence, the water absorption decreases steeply. Similarly, although slightly lower values have been reported for Turkish ceramic clays [20], the closure of porosity is also due to the anisotropic expansion of clays during heating [21].

In the Terra Alta kaolinitic clays the intersection in the gresification curves occurs in a range of temperatures between 1100 and $1250{ }^{\circ} \mathrm{C}$ (Fig. 3). A linear shrinkage respect to water absorption plot defined a field for the firing behaviour of commercial kaolins [22]. In the case of the Terra Alta, most clays plot in these conditions at $1200{ }^{\circ} \mathrm{C}$ (Fig. 4). In some cases, the PnB kaolin plots at the left of this area because the temperature of sintering are lower than $1200{ }^{\circ} \mathrm{C}$, whereas some kaolins of HS require higher firing temperatures, up to $1250{ }^{\circ} \mathrm{C}$.

The firing curve allows us to establish the rates of temperature of firing in the kiln according to the firing - expansion behaviour of the sample. The procedure for obtaining the firing curve is being carried out from the dilatometric curve. Using this, a heating curve is drawn as follows: the sintering temperature is sub-divided into steps with different time-temperature ratios in all kiln types [23]. In the steps where the highest expansion or shrinkage is observed the heating or cooling rate must slow down to avoid the development of instability points. Figure $5 \mathrm{a}$ and $\mathrm{c}$ shows the heating curves of $\mathrm{Hs}$ and PnB clays. In these curves the points A', B, $\mathrm{C}$ and $\mathrm{D}$ are being used to define the timing of the process in the kiln. The time of firing must proportionally distribute the expansion between the start of firing $\left(A^{\prime}\right)$ and the end of firing $(D)$. Points $B, C$ and $W$ correspond to a greater shrinkage, and then here a slower heating rate will be necessary. Point $B$ represents shrinkage due the $\alpha-\beta$ quartz transformation and clay dehydroxylation; $W$ corresponds to the $\beta$ - $\alpha$ quartz change during cooling, with a significant increase in volume. In this point, if the rate of cooling is high, stress can be developed. From the heating curve the firing curve was obtained (Fig. 5b and d), which shows a $24 \mathrm{~h}$ heating-cooling timing for Hs and PnB kaolinitic clays. The HS clays have to be fired at higher temperature than PnB clays. This is in agreement with the results from the gresification curves (Fig. 3).

The test pieces present crystalline and amorphous phases product of the transformation of the original minerals during firing. A semiquantitative quantification of the crystalline phases is shown in Fig. 6. Quartz is the most abundant mineral of the raw materials, with $48-86$ mas\%, which is unstable at temperatures higher than $1150{ }^{\circ} \mathrm{C}$ and is partly transformed into cristobalite, as typically occur in the production of ceramics [24, 25]. Cristobalite is the polymorph of silica stable between 1470 and $1725^{\circ} \mathrm{C}$ [26], however, the presence of defects in the quartz structure can induce the nucleation of cristobalite at lower temperatures [27]. In 

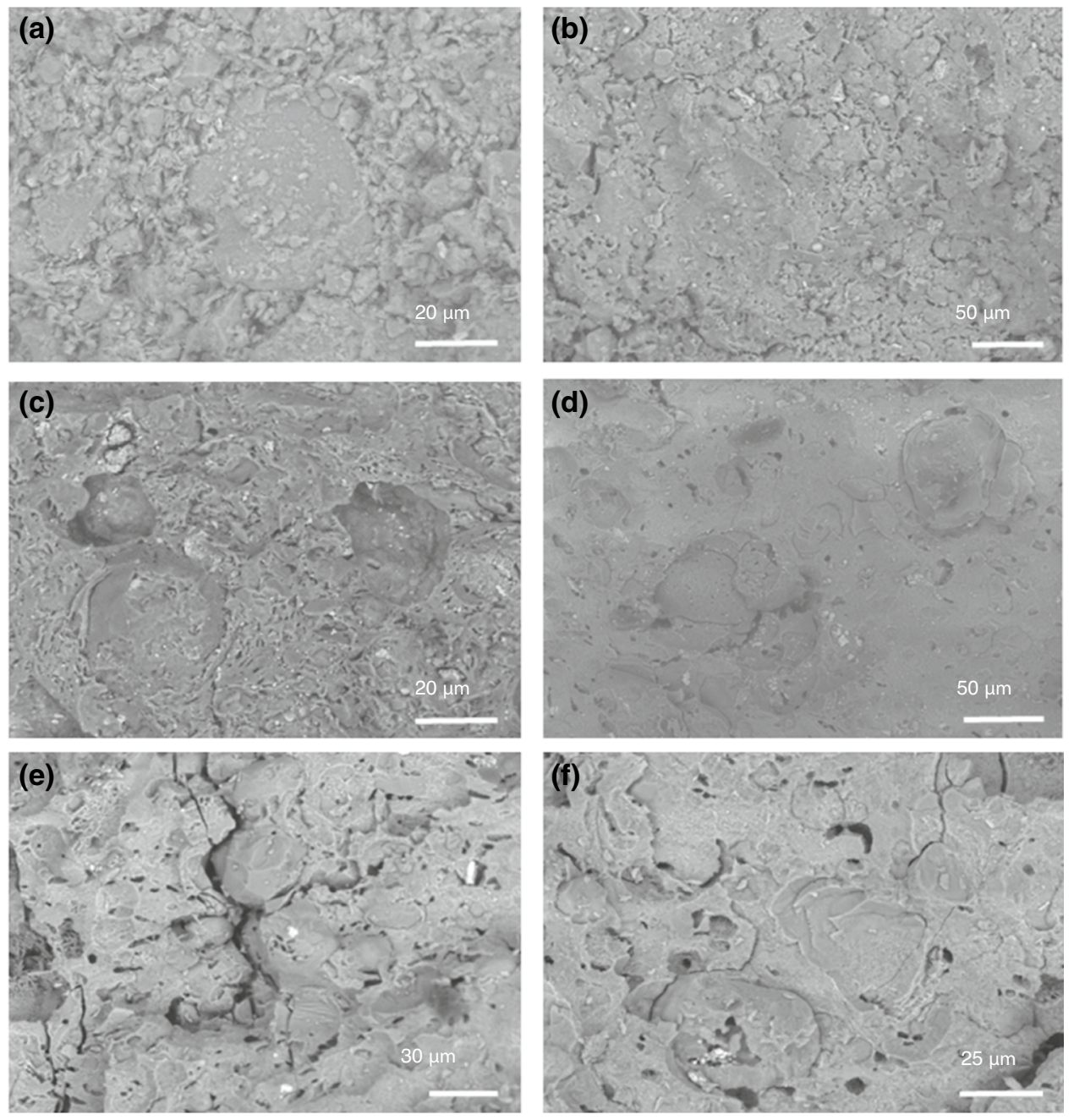

Fig. 8 SEM images of fired kaolins. a HS, $1050{ }^{\circ} \mathrm{C}$; b HS, $1200{ }^{\circ} \mathrm{C}, \mathbf{c} \mathrm{PnB}, 1250{ }^{\circ} \mathrm{C}, \mathbf{d ~ P n B}, 1300{ }^{\circ} \mathrm{C}, \mathbf{e ~ P n B}, 1050{ }^{\circ} \mathrm{C}, \mathbf{f} \operatorname{PnB}, 1200{ }^{\circ} \mathrm{C}$

Terra Alta near 40 mass $\%$ of quartz was transformed into cristobalite at $1300{ }^{\circ} \mathrm{C}$.

Kaolinite, 13-27 mass\% in the raw materials, is unstable at high temperature and changes first to metakaolinite and this to mullite. The amount of mullite content depends on the alumina present in the raw material. Mullite can be formed from clays and also from feldspar, this last is called secondary mullite and forms at $1200{ }^{\circ} \mathrm{C}$ [28]. In Terra Alta the crystallization of mullite is evident at the beginning of sintering, which in $\mathrm{HS}$ occurs at $1150{ }^{\circ} \mathrm{C}$ (Fig. 7) and in PnB at $1050{ }^{\circ} \mathrm{C}$ and reach the highest content between 1250 and $1300{ }^{\circ} \mathrm{C}$ (Fig. 6), being the total amount of mullite in the fired bricks from 33 to 37 mass\% (Fig. 6).

There textural characterization of pieces fired at different temperatures was observed in a fracture surface. The macroscopic observation of the surface of the pieces shows a uniform structure. Under the SEM a more complex texture is observed. In the HS clays the sintering process begins at higher temperature and at $1050{ }^{\circ} \mathrm{C}$ the lack of sintering still can be observed (Fig. 8a-b). In PnB clays the sintering process is observed from $1050{ }^{\circ} \mathrm{C}$ with the occurrence of orbicular grains of quartz and a glassy phase with rounded cavities corresponding a negative quartz crystals and small pores (Fig. $8 \mathrm{c}-\mathrm{d}$ ). The porosity becomes less abundant from $1050{ }^{\circ} \mathrm{C}$ up to $1300{ }^{\circ} \mathrm{C}$ (Fig. 8e-f). Mullite crystals cover the porosity surface from $1150{ }^{\circ} \mathrm{C}$. At $1250{ }^{\circ} \mathrm{C}$ a millimetre-sized round phases corresponding to hematite are observed (Fig. 9). 

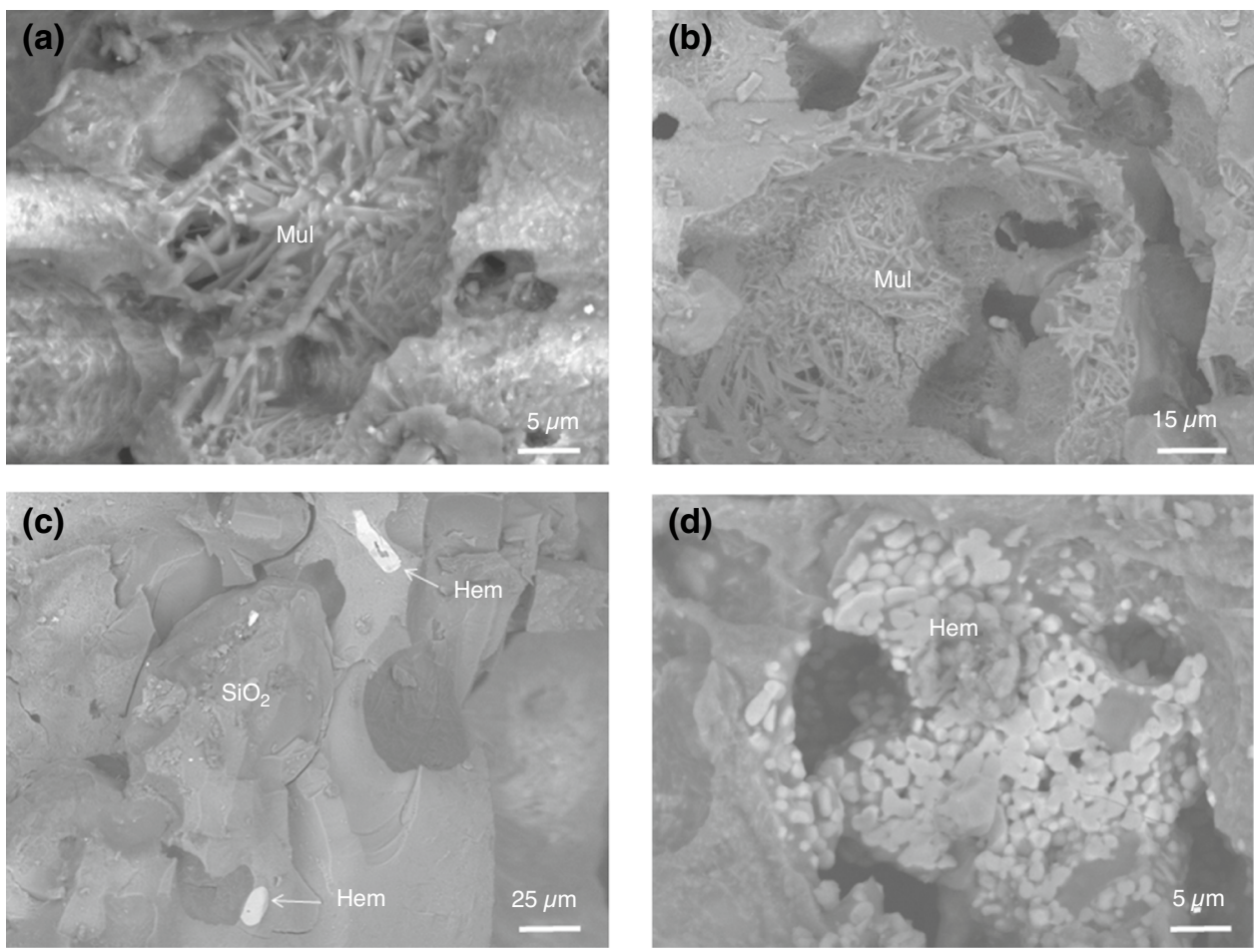

Fig. 9 SEM images showing the formation of mullite and hematite in fired PnB kaolin. a $1050{ }^{\circ} \mathrm{C}, \mathbf{b} 1200{ }^{\circ} \mathrm{C}, \mathbf{c} 1050{ }^{\circ} \mathrm{C}, \mathbf{d} 1200{ }^{\circ} \mathrm{C}$

(a)

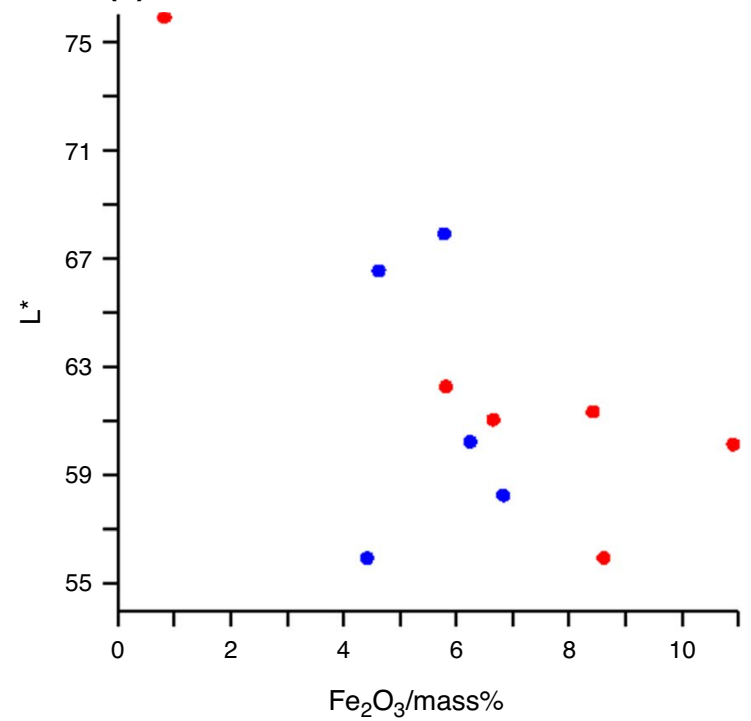

(b)

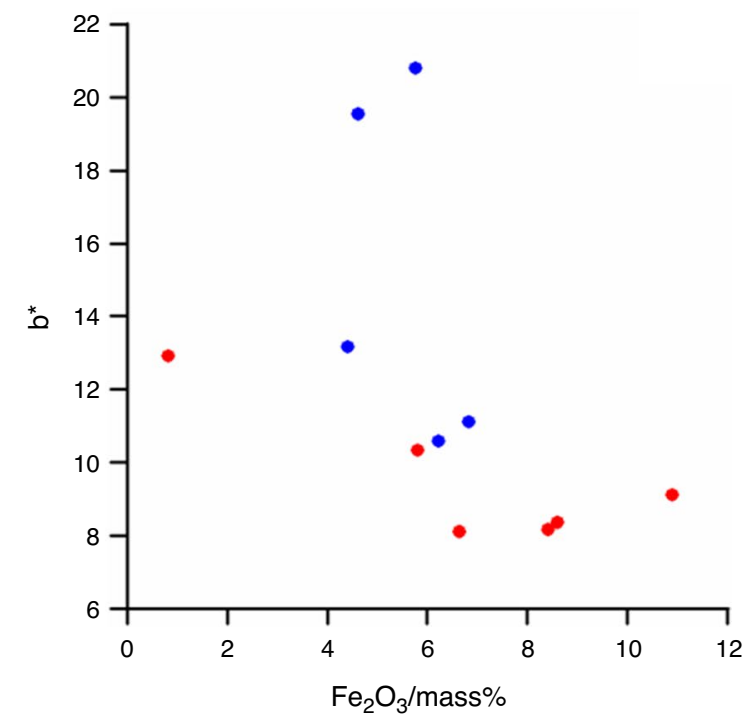

Fig. 10 Influence of the $\mathrm{Fe}_{2} \mathrm{O}_{3}$ content in the CIELab parameters in the Terra Alta kaolinitic clays. a $\mathrm{Fe}_{2} \mathrm{O}_{3}$ versus $L^{*}, \mathbf{b} \mathrm{Fe}_{2} \mathrm{O}_{3}$ versus $b^{*}$ 
(a)

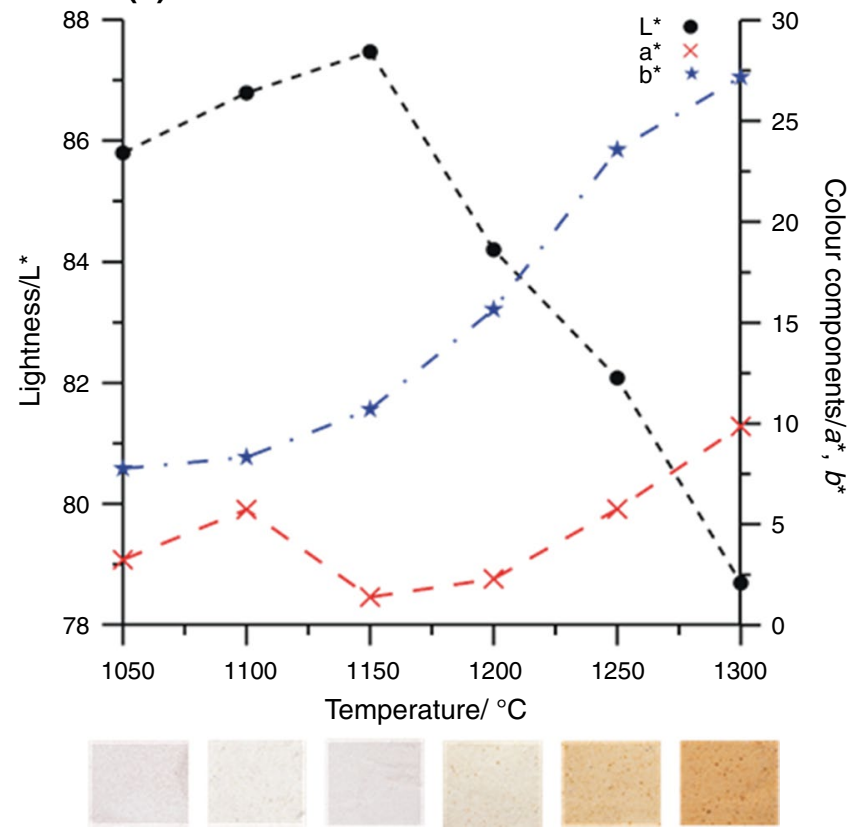

(b)

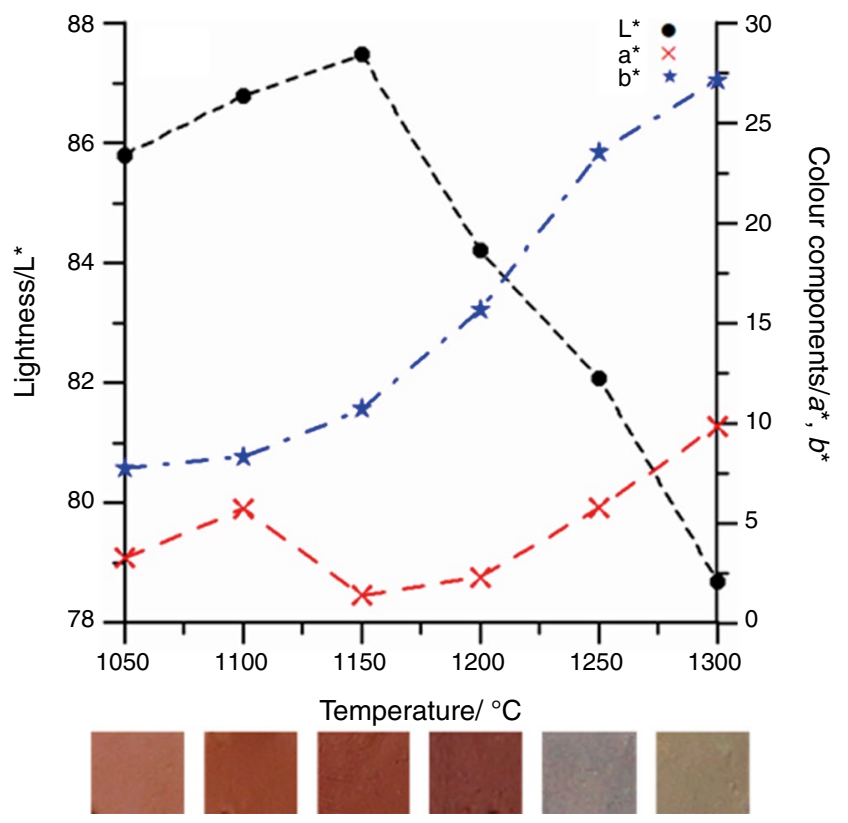

Fig. 11 Evolution of the colour parameters $\left(L^{*}, a^{*}, b^{*}\right)$ with the firing temperature. a HS, b PnB

\section{Colour}

The raw kaolinitic clays have a diversity of colours from pale white to reddish. The colour of kaolinitic clays changed after firing, thus, colour depends mainly of the $\mathrm{Fe}_{2} \mathrm{O}_{3}$ and $\mathrm{TiO}_{2}$ content but also of the mineralogy of the fired products.

The colour of the natural kaolinitic clays was described by their $L^{*}, a^{*}$ and $b^{*}$ parameters. The lightness, $L^{*}$, usually is related to the $\mathrm{Fe}_{2} \mathrm{O}_{3}$ and $\mathrm{TiO}_{2}$ content. In The terra Alta clays $L^{*}$ decreases with the $\mathrm{Fe}_{2} \mathrm{O}_{3}$ content (Fig. 10). In the fired test pieces made with $\mathrm{Fe}$-poor material $L^{*}$ increases with the temperature up to about $1150{ }^{\circ} \mathrm{C}$, and decreases from this value. The chromatic coordinate $a^{*}$ of the fired kaolinitic clays increases between 1100 and $1125^{\circ} \mathrm{C}$ (Fig. 10). This increase can be attributed to the destruction of the structure of illite, which causes the liberation of $\mathrm{Fe}^{3+}$ that is in substitution of $\mathrm{Al}$ in clays, and goes to substitute $\mathrm{Al}$ in the structure of the new phases formed [29] or crystallizes as hematite, which drives to the reddish colours $[19,30]$.

The decrease in the chromatic coordinate $a^{*}$ at high temperatures could be due to the formation of mullite, which can capture the hematite causing whiter or cream tones [19]. In the fired test pieces made with hematite-bearing materials $L^{*}$ decreases with the temperature up to about $1200{ }^{\circ} \mathrm{C}$, and increases from this value. The difference between the two $L^{*}$ curves (Fig. 11) is due to the fact that the sintering starts at different temperatures; sintering occurs later in HS clays, which means that the formation of newly formed crystals of
$\mathrm{Fe}$ and/or rutile oxides also occurs at higher temperature and therefore the decrease in $L^{*}$ begins later. On the other hand, the increase in $L^{*}$ again also suffers a delay in this case, it would be expected that in HS at a temperature greater than $1300{ }^{\circ} \mathrm{C}$ the value of $L^{*}$ increases, probably due to the reduction of $\mathrm{Fe}^{3+}$ to $\mathrm{Fe}^{2+}$ [29].

\section{Conclusions}

The Kaolinitic clays of Terra Alta are mainly composed of quartz and kaolinite, with minor feldspar, illite, hematite, and rutile. During sintering mullite and cristobalite are formed. Mullite begins to be formed at $1050{ }^{\circ} \mathrm{C}$ in $\mathrm{PnB}$ clays and up to $1150{ }^{\circ} \mathrm{C}$ in HS clays and increases up to $1250-1300{ }^{\circ} \mathrm{C}$; at these temperatures 40 mass\% of quartz has been transformed to cristobalite.

The relationships between water absorption and linear shrinkage, or gresification curves, indicate that the optimal firing temperatures are from 1100 to $1250{ }^{\circ} \mathrm{C}$, being the highest temperatures necessary for sintering the HS kaolin. In the Terra Alta clays, the shrinkage increases slowly up to $1050{ }^{\circ} \mathrm{C}$ and $1200{ }^{\circ} \mathrm{C}$, in $\mathrm{HS}$ and $\mathrm{PnB}$ clays, respectively. At this temperature a sharp increase is produced due to the appearance of a liquid phase. The increase in shrinkage decreases the porosity and thus, reduces the facility of water circulation into the ceramic pieces.

The rate of temperature of firing in the kiln was established according to the firing-expansion behaviour of the 
clays. The firing curves show that the rate of temperature rise in the kiln during the industrial ceramic production should be slow at the intervals where the expansion and shrinkage are greater, that is, at the $\alpha-\beta$ quartz transformation, the dehydroxylation of hydrous mineral phases during heating and at the $\beta-\alpha$ quartz transformation during the cooling process. The HS clays have to be fired at higher temperature than PnB clays.

The raw kaolinitic clays from Terra Alta exhibit a wide diversity of colours from pale white to reddish. Fired clays show lower lightness than the original materials. In the fired test pieces made with Fe-rich clays, $L^{*}$ decreases when the sintering process starts, and increases again when most sintering has occurred, between 1200 and $1250{ }^{\circ} \mathrm{C}$. In the fired test pieces made with $\mathrm{Fe}$-poor clays $L^{*}$ increases with the temperature up to the sintering process starts, about $1150{ }^{\circ} \mathrm{C}$, and decreases from this value. This decrease in $L^{*}$ at high temperatures could be attributed to the formation of mullite, which can capture the Fe oxides. Then, the firing temperature has a direct incidence in the colour of the fired clays.

Acknowledgements This research was financed by the projects 2017SGR1687 and 2017SGR0707 (Generalitat de Catalunya).

Author contributions MG and PA wrote the paper; DC, PA and MG did the laboratory work; SM assisted with the interpretation of results. All authors did the field work and contributed to data interpretation and discussion.

Funding Open Access funding provided thanks to the CRUE-CSIC agreement with Springer Nature. This research was financed by the 2017SGR1687 and 2017SGR0707 projects (Generalitat de Catalunya).

\section{Declarations}

Conflicts of interest No conflicts of interest.

Consent to participate All authors agree with the content and all gave consent to submit this manuscript.

Consent for publication All authors gave their permission of publication.

Open Access This article is licensed under a Creative Commons Attribution 4.0 International License, which permits use, sharing, adaptation, distribution and reproduction in any medium or format, as long as you give appropriate credit to the original author(s) and the source, provide a link to the Creative Commons licence, and indicate if changes were made. The images or other third party material in this article are included in the article's Creative Commons licence, unless indicated otherwise in a credit line to the material. If material is not included in the article's Creative Commons licence and your intended use is not permitted by statutory regulation or exceeds the permitted use, you will need to obtain permission directly from the copyright holder. To view a copy of this licence, visit http://creativecommons.org/licenses/by/4.0/.

\section{References}

1. Kurovics E, Kotova OB, Gömze LA, Shushkov DA, Ignatiev GV, Sitnikov PA, Ryabkov YI, Vaseneva IN, Gömze LN. Preparation of particle-reinforced mullite composite ceramic materials using kaolin and IG-017 bio-origin additives. Epa-J Silic Based Compos Mater. 2019;71(4):114-9.

2. Hubadillah SK, Othman MHD, Matsuura T, Ismail AF, Rahman MA, Harun Z, Jaafar J, Nomura M. Fabrications and applications of low cost ceramic membrane from kaolin: a comprehensive review. Ceram Int. 2018;44(5):4538-60.

3. Chen CY, Tuan WH. The processing of kaolin powder compact. Ceram Int. 2001;27:795-800.

4. Cargnin M, Ulson de Souza SMAG, Ulson de Souza AA. Modeling and simulation of the effect of the firing curve on the linear shrinkage of ceramic materials: laboratory scale and industrial scale. Br J Chem Eng 2015;32(2):433-43.

5. Partyka J, Gajek M. Effect of firing condition on ceramic glaze colour tonality. Interceram. 2012;61(5):270-6.

6. Valanciene V, Siauciunas R, Baltusnikaite J. The influence of mineralogical composition on the colour of clay body. J Eur Ceram Soc. 2010;30(7):1609-17.

7. Jordán MM, Martín-Martín JD, Sanfeliu T, Gómez-Gras D, de la Fuente C. Mineralogy and firing transformations of permotriassic clays used in the manufacturing of ceramic tile bodies. Appl Clay Sci. 2009;44(1-2):173-7.

8. Garcia-Valles M, Alfonso P, Martínez S, Roca N. Mineralogical and thermal characterization of kaolinitic clays from Terra Alta (Catalonia, Spain). Minerals. 2020;10(2):142.

9. UNI EN ISO 10545-13, Determination of water absorption, apparent density, apparent relative density and bulk density. 2000.

10. Moore DM, Reynolds RC Jr. X-ray diffraction and the identification and analysis of clay minerals. 2nd ed. New York: Oxford University Press; 1997.

11. Vasić MV, Pezo L, Zdravković JD, Bačkalić Z, Radojević Z. The study of thermal behavior of montmorillonite and hydromica brick clays in predicting tunnel kiln firing curve. Constr Build Mater. 2017;150:872-9.

12. CIE. Technical report, colorimetry. Commission Internationale de L'Eclairage, 1931.

13. McGuire RG. Reporting of objective color measurements. HortScience. 1992;27:1254-5.

14. Percival HJ, Duncan JF, Foster PK. Interpretation of the kaolinite-mullite reaction sequence from infrared absorption spectra. J Am Ceram Soc. 1974;57(2):57-61.

15. Húlan T, Kaljuvee T, Štubňa I, Trník A. Investigation of elastic and inelastic properties of Estonian clay from a locality in Kunda during thermal treatment. J Thermal Anal Calorim. 2016;124(3):1153-9.

16. Ramachandran VS, Paroli RM, Beaudoin JJ, Delgado AH. Handbook of thermal analysis of construction materials. Devon, UK: Noyes Publications; 2002.

17. Ptáček P, Křečková M, Šoukal F, Opravil T, Havlica J, Brandštetr J. The kinetics and mechanism of kaolin powder sintering I. The dilatometric CRH study of sinter-crystallization of mullite and cristobalite. Powder Technol. 2012;232:24-30.

18. Baccour H, Medhioub M, Jamoussi F, Mhiri T. Influence of firing temperature on the ceramic properties of Triassic clays from Tunisia. J Mater Process Technol. 2009;209(6):2812-7.

19. Barba AB, Beltrán V, Feliu C, García J, Ginés F, Sánchez E, Sanz V. Materias primas para la fabricación de soportes de baldosas cerámicas. Instituto de Tecnologia Cerámica; 2002. 
20. Çelik H. Technological characterization and comparison of two ceramic clays used for manufacturing of traditional ceramic products in Turkey. Mining. 2017;56(4):137-47.

21. Darbari Z, Jaradat KA, Abdelaziz SL. Heating-freezing effects on the pore size distribution of a kaolinite clay. Environ Earth Sci. 2017;217(76):1-8.

22. Ligas P, Uras I, Dondi M, Marsigli M. Kaolinitic materials from Romana (north-west Sardinia, Italy) and their ceramic properties. Appl Clay Sci. 1997;12:145-63.

23. Bhattacharya A. Optimization of firing parameters for ceramic wares by thermal analysis. J Thermal Anal Calorim. 1997;49(3):1365-71.

24. Schneider H, Majdic A, Vasudevan R. Kinetics of the quartzcristobalite transformation in refractory-grade silica materials. In: Materials science forum. Switzerland: Trans Tech Publ Ltd; 1986. p. 91-102.

25. Lyu S, Wang Y, Huang J, Li T, Li D, Wang JK, Zhang J, Sun D, Yu P. Sintering behaviors and properties of porous ceramics derived from artificially cultured diatom frustules. J Am Ceram Soc. 2021;104(5):2378-87.

26. Pagliari L, Dapiaggi M, Pavese A, Francescon F. A kinetic study of the quartz-cristobalite phase transition. J Eur Ceram Soc. 2013;33(15-16):3403-10.
27. Shoval S, Champagnon B, Panczer G. The quartz-cristobalite transformation in heated chert rock composed of micro and crypto-quartz by micro-Raman and FT-IR spectroscopy methods. J Thermal Anal Calorim. 1997;50(1-2):203-13.

28. Montoya N, Serrano FJ, Reventós MM, Amigó JM, Alarcón J. Effect of $\mathrm{TiO}_{2}$ on the mullite formation and mechanical properties of alumina porcelain. J Eur Ceram Soc. 2010;30(4):839-46.

29. Bouzidi N, Siham A, Concha-Lozano N, Gaudon P, Janin G, Mahtout L, Merabet D. Effect of chemico-mineralogical composition on color of natural and calcined kaolins. Color Res Appl. 2014;39(5):499-505.

30. De Bonis A, Cultrone G, Grifa C, Langella A, Leone AP, Mercurio $\mathrm{M}$, Morra V. Different shades of red: the complexity of mineralogical and physico-chemical factors influencing the colour of ceramics. Ceram Int. 2017;43(11):8065-74.

Publisher's Note Springer Nature remains neutral with regard to jurisdictional claims in published maps and institutional affiliations. 